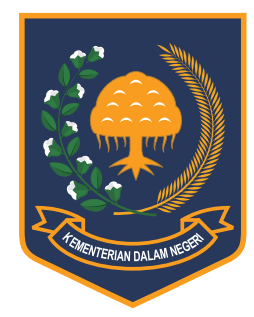

Jurnal Bina Praja 8 (2) (2016): 305-315

Jurnal Bina Praja

e-ISSN: 2503-3360 | p-ISSN: 2085-4323

Accreditation Number

735/AU2/P2MI-LIPI/04/2016

http://jurnal.kemendagri.go.id/index.php/jbp/index

\title{
THE IMPLEMENTATION OF SWOT ANALYSIS of People Economic Empowerment Business LoAn (KUPEM) in Jambi Province
}

\author{
Susi Desmaryani ${ }^{1, *}$ \\ ${ }^{1}$ Regional Research and Development Agency (Balitbangda) Jambi Province \\ Jl. R. M. Noor Admadibrata No. 1A
}

Received: 31 August 2016; Accepted: 6 October 2016; Published online: 30 November 2016

DOI: $10.21787 /$ ibp.08.2016.305-315

\begin{abstract}
The problems of SMEs today are generally only able to survive but rarely oriented towards growth and capacity development of the company. One of the problems that hinder the growth of SMEs is financing problems. The government has tried to provide financing assistance in the form of soft loans, one of which is KUPEM, but SMEs do not have the commitment to running the business with loans that have been granted by the government. This study aims to determine the implementation strategy of People Economic Empowerment Business Loan (KUPEM) in the Province of Jambi. The research method used was a case study with descriptive research type. The sample consists of 125 respondents. Sampling is conducted in a nonprobability sampling and purposive sampling. Data were analyzed using SWOT analysis. The results showed that the implementation of KUPEM by the Provincial Government of Jambi through internal analysis indicates the value of the power factor is still below the weakness factor. External analysis of People Economic Empowerment Business Loan still has a big opportunity than a threat factor. Therefore, People Economic Empowerment Business Loan continues because it can help the growth of the community effort by making strategic changes. Result of the study recommend to strengthen internal factors which are the analytical skills of relevant agencies that are trusted to provide recommendations for KUPEM loans, (1) Relevant agencies create mentoring programs to enhance the ability of SMEs actors, (2) Through the relevant agencies forming a group of associations between groups of SMEs, (3) Increasing motivation to make MSMEs business through counseling activity, and improve the competence of field educators, (4) Conduct analysis of the suitability of business in accordance with local conditions (in this case the state of nature, the public taste and the target market).
\end{abstract}

Keywords: SWOT analysis, credit, SMEs.

\section{INTRODUCTION}

Government's role as a motivator, catalyst, regulator and facilitator in developing the micro, small and medium enterprises have not been welcomed by the business actors, many businesses found not able to utilize the credit support provided by the government. This is happening because SMEs still have limitations in managing finances which are limited knowledge about bookkeeping and lack of separation between personal finances and business finances, thus making the credits earned cannot be used optimally. (Ministry of Trade, 2013).

Tight controlling on budget and financing is one of the weaknesses of SMEs, according to Saragih and Surikayanti (2015) small businesses have a small budget, as a result they often forced to divide the funds to finance various needs as efficiently as possible, and the impact on business operations resulting in shortage of venture capital. Operational funding shortage that could not be prevented will usually lead to bankruptcy because SMEs do not have the capacity to pay the debt.

Meanwhile, economic growth in Indonesia is largely dominated by micro, small and medium enterprises (SMEs). Moreover, SMEs are the type of business that can survive in the midst of the economic crisis that hit Indonesia, because it has the raw materials come from local content. The ILO reported that $60 \%$ of workers in the cities of

\footnotetext{
* Corresponding Author

Phone : +6281312453338

Email : Susidesmaryani@yahoo.com
} 
developing countries are absorbed by the informal sector and the activities of the small and medium enterprises. The role of the SME sector is very important because it can create the market, expand trade, manage natural resources, reduce poverty, create jobs, build communities and support their families without adequate control and facilities from the local government (ILO, 1991 and Reddy et.al., 2002). In Indonesia, the SME sector even becomes the foundation of life since the economic crisis that began in 1997 (Sarosa, 2000).

Many government aid programs are given to the groups of SMEs, for example providing capital assistance in the form of loans with a low-interest rate. Sabirin (2001) explains that in order to empower the economically disadvantaged or small business sector is to provide a source of business financing or affordable credit. Increased credit services aimed at addressing the shortage of capital for households in developing a business (Diagne, et al., 2000 and Diagne, 2001) Capital is one of the problems faced by SMEs in maintaining its presence. But, there are other problems that arise which is the limited knowledge of business actors in managing the business, due to lack of knowledge causes most small and medium enterprises can only survive and rarely oriented towards growth, development in the capacity and the ability of the company (Gray, 2006).

Loans are given by the government, in fact, has not been utilized to the maximum by SMEs to develop the business, in addition to their limited ability to manage credits, loans given were being used for consumption rather than investment. Suji, Sutomo, and Mukti research results (2015) found that the misuse of the People's Business Credit (KUR) which was originally for the production, in reality, is used for consumption and not for investment that can provide a business advantage. If the use of credit were diverted for consumption it will cause the burden of unpaid debt. This is why loans become ineffective and have an impact on bad debts.

Other studies which support that the use of credits earned by SMEs has not been maximized to financing the company's operations, investigated by Purnamayanti, Suhendra, and Yulianthini (2015), the study found that the revenue of SMEs declined after receiving credit assistance. This occurred due to the capital obtained from the loan is not fully utilized for business capital.

Government needs to create a strategy to make the SMEs that received loans can feel the benefits of the loans to help to boost the economy, as loans for productive purposes provides an opportunity for households to start or expand a household business (Feder et al., 1990), so as to increase household income (Zeller et al., 1997). Cashmere (2010) stated that the credit can positively increase revenue because the credit is given to increase business capital.

Capital Problem is also a problem for SMEs in the province of Jambi in maintaining its existence. Jambi province has natural potential that capable of providing welfare for the people if the natural potential can be managed properly, it will have an impact on economic growth. Based on that condition, one of Jambi Provincial Government program is to help Micro, Small and Medium Enterprises in terms of credit provision known as Community Economic Empowerment Business Credit (KUPEM) as a way to overcome the problem of capital for SMEs in the province of Jambi.

The granting pattern of Community Economic Empowerment Business Credit (KUPEM) previously using executing patterns, and then switch to channeling, wherein the pattern of channeling the process of assessment and credit provision conducted by the Provincial Government of Jambi directly through the relevant working unit related to the type of business of the SMEs. The role of Banking in channeling pattern is just as the administration of payment and does not have the legal authority to follow up violations of inability to repay loans that had been granted by the Provincial Government of Jambi. The pattern of channeling got a different interpretation from the business actors resulting in a credit crunch. The survey results found that there was credit aid that is not targeted and business empowerment program was not carried out intensively to develop the business of SMEs groups. This is why businesses are difficult to survive and even to grow and thrive.

The desired expectation is actually a credit assistance provided by the government can raise revenue of SMEs so that SMEs have the ability to pay credit obligations. Therefore, the government's role is not limited to providing funding, but more to the empowerment of SMEs so that SMEs can grow and develop. So far, the perceived role of government is limited to providing credit but not oriented to the empowerment of SMEs to the maximum, so that the credit assistance can improve the SMEs business. This is in line with research conducted by Ferdian (2004) of the Community Small Business Empowerment through People's Economic Empowerment Program (PER) in Sabang City. The results showed that the PER program through the provision of soft loans to people in Sabang has been running as expected by the local government. But the program had an image of only project funding loans with low-interest rate because the process that uses the concept of empowerment was still minimum. Community empowerment has not touched all aspects of the stages of the provision of soft loans to small entrepreneurs.

Other studies that are in line was the research 
done by Kurniawan and Fauziah (2014) on the Empowerment of Micro, Small and Medium Enterprises (SMEs) in Poverty Reduction, the research states that the empowerment process that has been done by the government was only to the extent of providing business capital and lack of effort in developing the Micro, Small and Medium Enterprises (SMEs).

Effort to improve the performance of SMEs, the government not only help provide credit but more broadly to mention the role of the government in an attempt to empower SMEs as stipulated in Law No 20 Year 2008, it is expected that the People Economic Empowerment Business Loan (KUPEM) that granted to SMEs can increase revenues.

The study results of Murdy (2010) on the Role KUPEM in Increasing Potato Production in Kerinci District of Jambi, has shown that KUPEM fund is beneficial to farmers. The capital assistance that helps to increase potato production had an impact also on increasing farmers' income. While studies of Setyari (2012) titled "Impact Evaluation of Microcredit on Household Welfare in Indonesia" This study has shown a strong result that microcredit gave a positive significant impact on the level of household welfare in Indonesia in terms of upgrading the amount of spending per capita and labor supply of households receiving the program. However, it did not show a significant impact on the level of education of children even it revealed the presence of adverse effects mechanism. Credit which was use for expansion mostly will utilize household labor, so that the children could help the family business and they were able to employ children in micro-enterprises. Based on the results of both studies, it showed that the credit received by the public can increase revenue.

In addition, both studies also showed that KUPEM can increase the ability of people in managing the debt of credit to become a source of household income in order to improve the quality of life.

The phenomenon of People Economic Empowerment Business Loan (KUPEM) implementation, generally in the province of Jambi, currently not able to increase revenue, this is due to the behavior of customers who have not been consistent in running the business, the ability of the customer is still limited to repay debt obligations after obtaining loans from government. The presence of loan funds provided by the government has not targeted based on predefined rules. Government assistance and business guidance to groups of SMEs are not intensively managed, therefore KUPEM given by the government have not been able to provide an opportunity for groups of SMEs to improve their business. Based on the issues contained in the implementation of KUPEM, this study will make the right strategy through a SWOT analysis regarding the implementation of People Economic Empowerment Business Loan (KUPEM), the purpose of this study is to find out the SWOT analysis of the KUPEM implementation in Jambi Province.

Business Loan Program for Community Economic Empowerment in Jambi Province is earmarked for the SMEs group in the field of agriculture, fisheries, animal husbandry and processing industry.

People Economic Empowerment Business Loan (KUPEM) are loans granted to farmers in the group members of crops, Horticulture, Fisheries, Livestock and Industry in order to finance the farming, small industries and home industries, also services and small trading in the city of Jambi and District in the province of Jambi.

Loans granted to the SME group using the pattern of small business loans specifically regulated in the implementation guidelines of KUPEM in accordance with Jambi Governor's decision No 369 of 2002 dated October 28, 2002. For the technical implementation in the management and development as well as implementation guidelines in the field, the first party QC. Relevant Department of each District/City respectively, in which the relevant agencies, among others, Agriculture, Fisheries, Animal Husbandry, Small Industry and Small Trade using KUPEM funds to develop business in each sector either through the groups or individuals through the recommendations given by the relevant authorities.

Based on the agreement between the Governor of Jambi and the Bank of Regional Development of Jambi No 01/PERj/OHK/I/2004 and No 2:01 .KP/. DIR, KUPEM Awarding is based on the provision stating that KUPEM reserved for farmers and entrepreneurs to the industry engaged in services and trade. The government gives requirements that must be met by the receiver, those are must have savings on Jambi Bank, the loan must be used for business capital, repayment of credit in maximum of 2 years, the way of credit repayment is adapted to the business results cycle, and doing some feasibility analysis before getting the loan. Conditions analysis of creditworthiness according to Munawir (2002) among others, viewed from: (a) Character, reflect the nature and character of prospective borrowers, (b) Capacity, to see the client's ability to manage its business, which is associated with the education, the ability to understand the provisions of the government and the ability of customers to restore their credit. (C) Capital, to see the effective use of capital, seen from the financial statements (balance sheet and income statement) by performing the measurement in terms of liquidity, solvency and profitability. (D) Collateral, to see the guarantees 
given by customers both physical and nonphysical and (e) Condition of Economic, conduct an assessment of the economic and political conditions.

KUPEM is a government program as an effort to reduce poverty. Through the credit, it is expected that the economic level and quality of life is getting better. People can develop the business through capital loans and become a strong entrepreneur.

Therefore, business actors are expected to grow to be entrepreneurs who have the attitude and behavior that can perform loan capital with the attitude and behavior of work achievement. According to Suryana (2003) Achiever is an entrepreneur who always ambitious and want to go forward (ambition driven) therefore an entrepreneur who wants to succeed in his business must not sluggish, surrender, did not want to fight, but has to be passionate, striving, and having the ambition to go forward with commitment to their work.

Suryana (2003) argues that attitudes and achiever working behavior can be characterized as follows: (1) Work with self-awareness in the emotional sense, entrepreneurs are required to always be careful in conducting their business, (2) Work smart, entrepreneurial ability to think precisely in overcoming all conditions, (3) Work Hard, show the spirit and capabilities of entrepreneurs to achieve the results desired, (4) Work sincerely, works without any complaints, keep fighting despite making mistakes, (5) Work completed is work that is capable of organizing part in an integrated effort from start to finish so that it can produce a maximum effort to finish with.

\section{METHOD}

The method used in this research surveys, research sites in East Tanjung Jabung, Sarolangun, Merangin, Batanghari and the city of Jambi. The study was a descriptive study.

The method of sampling in this study is a nonprobability sampling which is a sampling where the probability or chance of a person to be elected as a sample is unknown (Irawan Soehartono, 200: 59).

The sampling technique used in this study is purposive sampling (samples intended), given the limited time and funds, the investigator directly determines which SMEs group that can be reached directly.

The area selected as the sample in this study consisted of four (4) districts and cities, namely East Tanjung Jabung, Sarolangun, Merangin, Batanghari, and Jambi city. The basis for determining the sample was based on the area's which got many credit assistance and have ease of access for researchers to reach them.

The sampling technique to the respondent is by purposive sampling. Purposive sampling carried out due to consideration of the limitations of time, effort and funds so could not take a large sample and distant. Besides purposive sampling was done on purpose to note that the sample should represent the of the population to be studied. This sampling techniques aim is good enough because it is in accordance with the researcher's consideration themselves so they can represent the population. The advantage lies in the accuracy of researchers in selecting data source according to the variables studied (Sutrisno, 1993).

Based on Provisions of sample amount for respondents by Roscoe quoted in Sekaran (2006), it provide a common reference to determine the sample amount of more than 30 and less than 500 is appropriate for most research, therefore selected sample of the population is divided into two (2) categories, where the first category is customers who smoothly run their credit obligations. The second sample category is customers who have a problem in paying credit obligations (loss). The purpose of the determination of this sample category is to determine whether the process of conducting KUPEM by the government of Jambi Province is in conformity with the rules that apply to both categories of such customers. Thus, the total sample of this research consisted of 125 customers, 55 customers' with settled payment and 70 customers with problematic payments. 125 respondents considered as representatives to answer about the loan process by the government and the ability of customers or respondents to use credit for business development.

Data were analyzed using SWOT analysis through quantitative approach (Pearce and Robinson, 2008) and a qualitative approach through the matrix according to Kearns (in Salusu, 2003). SWOT illustrates the strengths and weaknesses as internal factors, opportunities and threats as external factors. The grouping of the factors that being included in the strengths, weaknesses, opportunities and threats are according to the observations of researchers that have been discussed through Focus Group Discussion (FGD).

SWOT with a quantitative approach using three step calculations (Pearce and Robinson, 2008), the first step is to give a score from each of the internal and external factors. Scores obtained from the average of respondents' answers, then give weight to internal and external factors to the sequence of importance. The level of importance starts from 1-4, (1) give meaning as not important, (2) give meaning as less important, (3) gives the meaning as quite important, and (4) give meaning as important. Furthermore, the total score is obtained by multiplying the average scores and weights. The second step to make cuts on internal factors, in which the total amount of strength reduced by the 


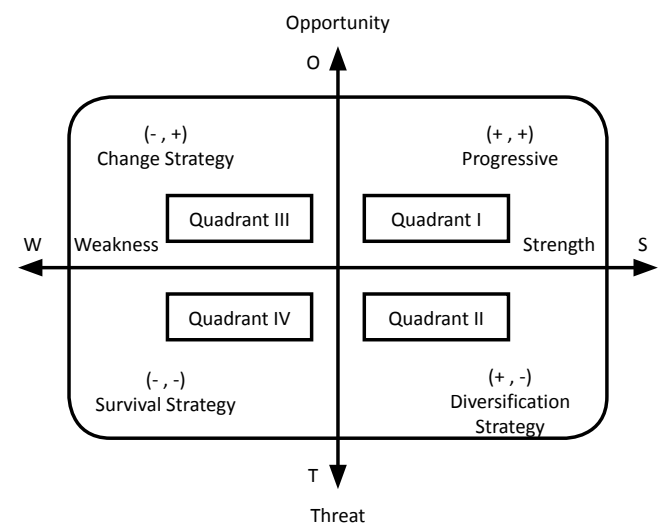

Figure 1. SWOT Quadrant

total amount of weakness $(\mathrm{d}=\mathrm{S}-\mathrm{W})$, then make cuts on external factors, in which the total amount of opportunity reduced by the total amount of threats $(e=0-T)$, scoring $(d=x)$, then it becomes the point of the X-axis, then the scoring $(e=y)$ to be a point of the Y-axis, the third step is searching for the axis point $(\mathrm{X}, \mathrm{Y})$ on SWOT quadrant as described in Figure 1.

For SWOT with the qualitative approach is using internal factors and external factors. Internal factors that incorporated into the matrix are called IFAS (Internal Strategic Factor Analysis Summary). External factors that incorporated into the matrix are called EFAS (External Strategic Factor Analysis Summary). After the matrix of internal and external factors completed, then the results were incorporated into the qualitative model, namely SWOT matrix to formulate the company' competitive strategy. The matrix factors for internal (IFAS) and external (EFAS) strategy.

Indicators for measuring internal factors is the provisions of People Economic Empowerment Business Loan implementation and external factors assessed on the attitudes and behavior of creditors after receiving the business credit for community economic empowerment.

SWOT Analysis on the external environment assessed on the attitudes and behavior of borrowers after receiving the business credit for community economic empowerment, to which extent is the ability of borrowers to manage credit for developing the business, and internal analysis to look at the provisions of the People Economic Empowerment Business Loan (KUPEM) implementation given by the government is already in line with the criteria which has been determined. The analysis of external and internal environment is then being outlined in the form of SWOT strategy as shown in the framework picture in Figure 2.

\section{RESULT AND DISCUSSION}

\section{A. Description of People Economic Empowerment Business Loan Implementation}

Methods for Granting Business Loan for Community Empowerment (KUPEM) with channeling pattern through the designated working unit (SKPD) disbursing credit to the business actor of Micro, Small and Medium Enterprises measured using indicators of the provisions set by the government.

Scheme of Distribution/Utilization/Repayment of KUPEM funds in Jambi province can be seen in Figure 3.

KUPEM delivery mechanism is carried out in seven stages. First, the credit application is done in groups/individuals to the Regent/Mayor through related Technical Office, through the submission provided by the related Technical Office. Submissions must be accompanied with RDKK which

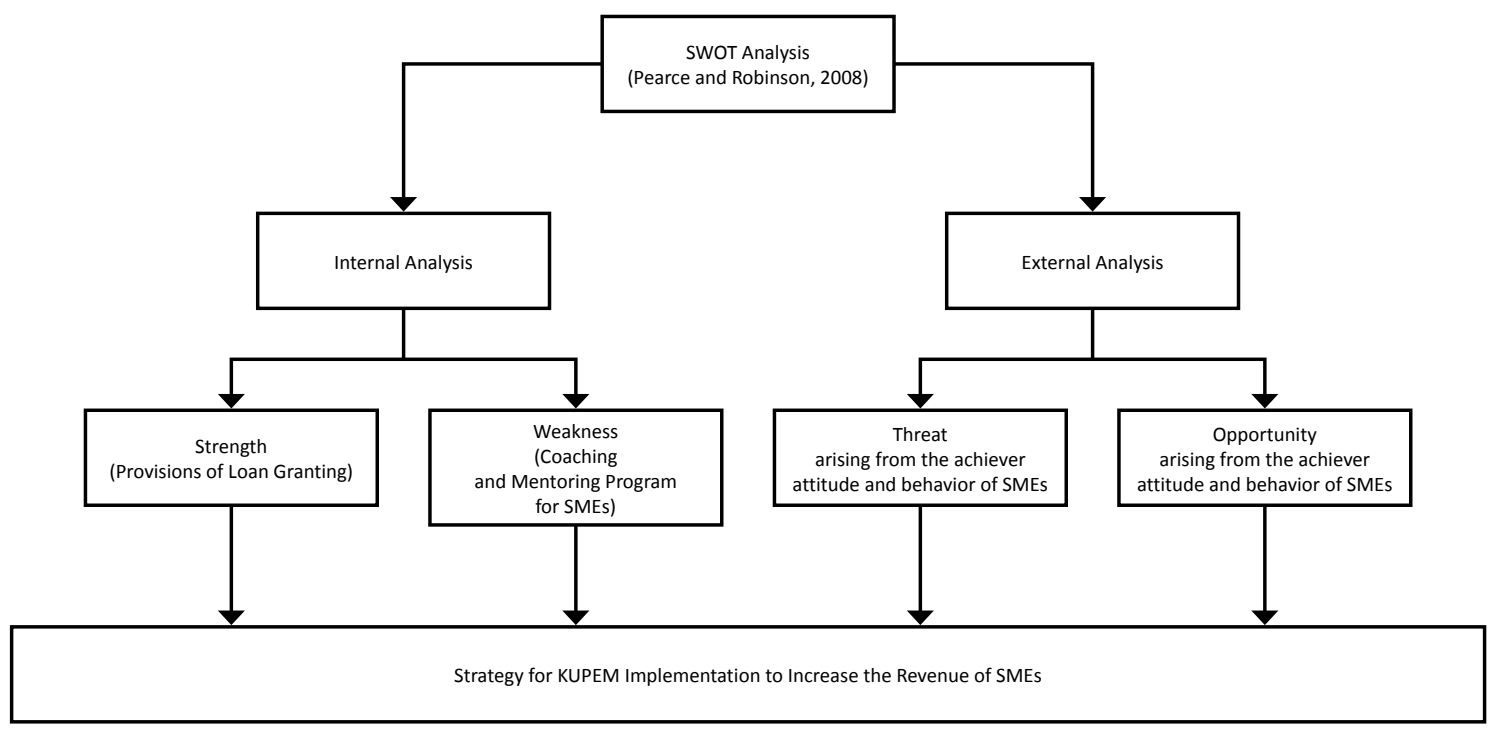

Figure 2. Framework Implementation of Business Loan for People Economic Empowerment in Jambi Province 


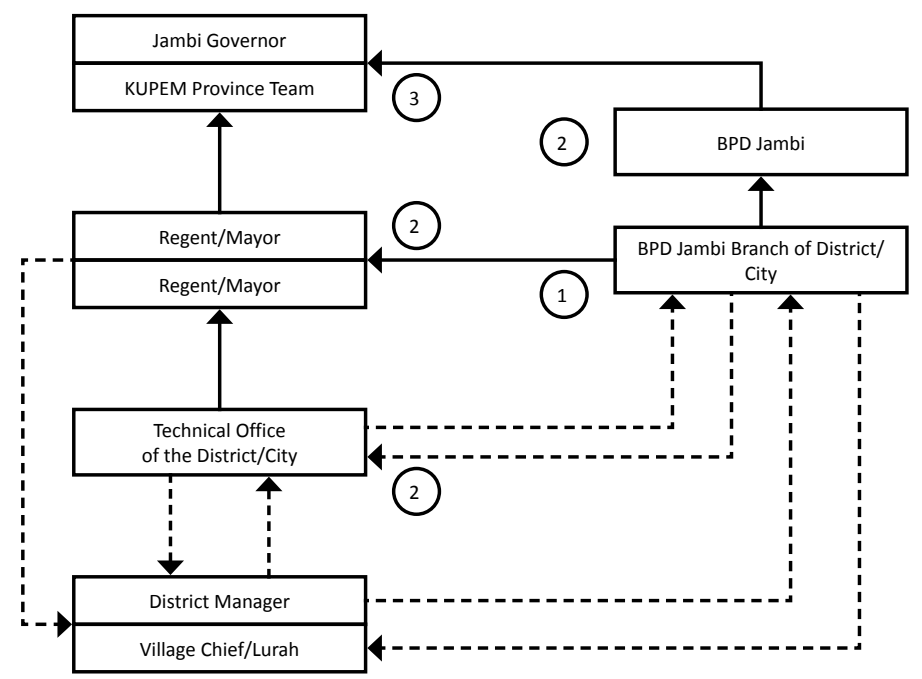

Figure 3. Scheme of Distribution/Utilization/Repayment of KUPEM funds in Jambi Province Sources: Bank Jambi (2014)

Explanation:

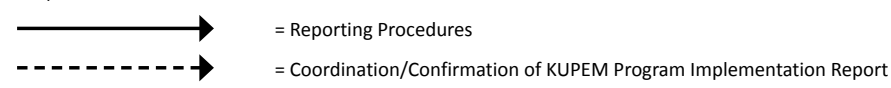

was approved by the related Technical Officers/ Department/Institution existing in its scouted region and known by the Village/District Head. Second, examine thoroughly on the feasibility of their business in the field together with the technical team of the District/Municipal and officials/ officer of Local BPD Branch. Third, after checking/ researching, the related technical Department/ Institutions propose to the Regent/Mayor to get a recommendation. Fourth, the Regent/Mayor receives the request and promptly recommended and submitted to the local branch of the BPD with a copy to Related Technical Office in Jambi Province. Fifth, BPD Jambi after receiving the application of KUPEM submitted by the Regent/Mayor as point 4 above are being processed immediately for the realization of the potential participants of KUPEM that has been recommended. Sixth, the technical implementation of the operational management of KUPEM distributions is governed by the Regent/ Mayor in accordance with the conditions and the situation of each district/city. Seventh, with the altered pattern of KUPEM management from executing into channeling, causing the responsibility of KUPEM implementation (Distribution, Utilization, and Development) becomes the responsibility of the Regent/Mayor.

Based on the answers of respondents, it turned out that SMEs in Jambi Province which received KUPEM assistance, gives no impact on the increase in revenue, they still not able to increase their income, but have an impact on the failure to pay the debt. The strategy needs to be made for the KUPEM implementation so that SMEs have the ability to manage credit which will turn into increasing revenue. Therefore, the strategy for the implementation KUPEM is measured through external factors and internal factors. External factors illustrate the opportunities and threats. Internal factors illustrate the strengths and weaknesses. Internal factors measured using indicators of KUPEM provisions. External factors are measured through attitudes and behavior of the borrowers (SMEs group) in managing the Economic Empowerment Business Loans granted by the government. Based on respondents' answers then described as follows:

1. Internal factors describe the KUPEM provisions that should be accepted by the SMEs groups, it shows the strengths and weaknesses of lending system undertaken by the government through working unit (SKPD) as described in Table 1.

2. External factors describe the obligations of borrowers to repay the debt as measured by the behavior of borrowers in developing venture capital through the analysis of the achieving attitudes and behavior of people after obtaining the KUPEM loan. Borrowers behavior is influenced by several external factors that bring opportunities and threats for KUPEM as described in Table 2.

\section{B. SWOT Analysis in the Implementation of KUPEM in Jambi Province}

Considering the credit given by the government is one of the government programs to reduce poverty, to show care and concern of the government in improving the welfare of the people, based on those reasons, the loan programs continue to be implemented. In order for the loan program from the government to run smoothly and can avoid 
Table 1.

Strengths and Weaknesses of Lending System

\begin{tabular}{|c|c|c|c|c|}
\hline No. & Strengths & $\begin{array}{l}\text { Average } \\
\text { Score }\end{array}$ & Weight & Total \\
\hline 1 & KUPEM destination is on the right target which is SMEs & 3.46 & $2 / 4$ & 1.73 \\
\hline 2 & $\begin{array}{l}\text { Distribution of the amount of loans granted in accordance with the ability } \\
\text { of borrowers to meet monthly obligations, as measured by the capacity on } \\
\text { business results }\end{array}$ & 3.31 & $3 / 4$ & 2.48 \\
\hline 3 & $\begin{array}{l}\text { SKPD/Working Unit ability to provide guidance so loans can develop the } \\
\text { business, so that borrowers can meet debt obligations in accordance with the } \\
\text { collective agreement. }\end{array}$ & 3.18 & $4 / 4$ & 3.18 \\
\hline 4 & $\begin{array}{l}\text { Time Period, determination of maturity that has been agreed between } \\
\text { borrowers and SKPD (Working Unit) }\end{array}$ & 3.16 & $2 / 4$ & 1.58 \\
\hline & Total Achievement Value of Strength & & & 8.97 \\
\hline No. & Weaknesses & $\begin{array}{l}\text { Average } \\
\text { Score }\end{array}$ & Weight & Total \\
\hline 1 & Guidance to SMEs in managing the business. & 2.27 & $4 / 4$ & 2.27 \\
\hline 2 & Analysis of suitability between the business type and the potential of the area. & 2.94 & $4 / 4$ & 2.94 \\
\hline 3 & $\begin{array}{l}\text { Disseminating information to potential borrowers regarding liability and } \\
\text { sanctions that should be run. }\end{array}$ & 2.87 & $3 / 4$ & 2.15 \\
\hline 4 & $\begin{array}{l}\text { Analysis of the financial statements of potential borrowers had not been } \\
\text { effective. }\end{array}$ & 2.30 & $4 / 4$ & 2.30 \\
\hline \multicolumn{4}{|c|}{ Total Achievement Value of Weakness } & 9.66 \\
\hline
\end{tabular}

Difference between the strengths and weaknesses $S-W=8.97-9.66=-0.69$

Table 2.

Opportunity and Threat of Lending System

\begin{tabular}{|c|c|c|c|c|}
\hline No. & Opportunity & $\begin{array}{l}\text { Average } \\
\text { Score }\end{array}$ & Weight & Total \\
\hline 1 & $\begin{array}{l}\text { Borrowers (SMEs groups) have had behavioral attitudes which do not discourage } \\
\text { and conscientious in doing business }\end{array}$ & 3.03 & $3 / 3$ & 3.03 \\
\hline 2 & Personal factors such as the urge to succeed are more dominant & 3.16 & $2 / 3$ & 2.10 \\
\hline 3 & $\begin{array}{l}\text { Borrowers (SMEs group) have character and behavior to be careful in running } \\
\text { the business to avoid failure. }\end{array}$ & 3.16 & $3 / 3$ & 3.16 \\
\hline \multirow[t]{2}{*}{4} & $\begin{array}{l}\text { The presence of encouragement from themselves to succeed and become an } \\
\text { example for other SMEs. }\end{array}$ & 2.92 & $4 / 4$ & 2.92 \\
\hline & Total Achievement Value of Opportunity & & & 11.21 \\
\hline No. & Threat & $\begin{array}{l}\text { Average } \\
\text { Score }\end{array}$ & Weight & Total \\
\hline 1 & $\begin{array}{l}\text { The lack of knowledge of SMEs in terms of bookkeeping, and enhance the } \\
\text { entrepreneurial skills. }\end{array}$ & 2.67 & $4 / 4$ & 2.67 \\
\hline 2 & $\begin{array}{l}\text { Social factors affecting SMEs in determining the attitudes and behavior in doing } \\
\text { business. }\end{array}$ & 2.92 & $2 / 4$ & 1.46 \\
\hline 3 & $\begin{array}{l}\text { In doing business, borrowers (SMEs groups) have not been oriented to the } \\
\text { achievement of the target. }\end{array}$ & 2.89 & $3 / 4$ & 2.16 \\
\hline & Total Achievement Value of Threat & & & 6.29 \\
\hline
\end{tabular}

Difference between the opportunity and threat $\mathrm{O}-\mathrm{T}=11.21-6.29=4.92$

The Implementation of SWOT Analysis

of People Economic Empowerment Business Loan (KUPEM)

in Jambi Province 


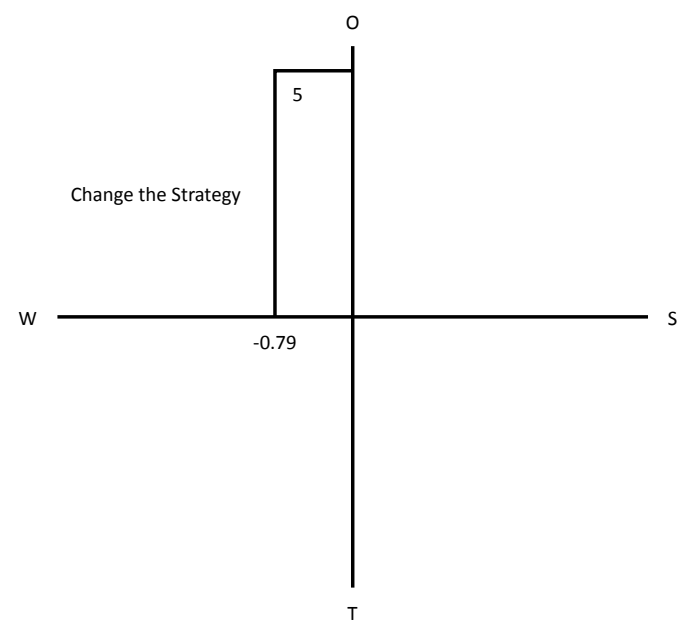

Figure 4. SWOT Diagrams and KUPEM Strategy Implementation

bad credit, there should be a strategy which is ideal for the implementation of KUPEM.

The inability of SMEs in the province of Jambi to manage KUPEM funds into revenue, due to the behavior of business actors have not oriented on results of operations, the use of credit funds have not been maximized to create products and services that can meet the needs of the market. Most of the products do not follow the development of consumer tastes, moreover in doing business they do not predict whether the effort carried out in accordance with the geographical conditions that would have a negative impact on production output. To overcome the unintended consequence from misapplication of funds provided by the government, it is necessary to have business guidance and coaching from the related working unit (SKPD) so that the loan funds which have been granted can be used appropriately and can help people to develop their business.

SWOT analysis is based on the analysis of internal factors which consists of strengths and weaknesses, opportunities and threats from external factors. The results of the internal analysis in Table 1 were measured through the provisions of KUPEM implementation and coaching and mentoring programs provided by the government. And external analysis as measured by the achieving nature and behavior of SMEs that give impact on the opportunities and threats in the business, thus the strategy that will be implemented can be illustrated in SWOT diagrams and matrix which can be seen in Figure 4.

Based on Figure 4, the KUPEM is in quadrant III, which changes the strategy, it means KUPEM must make strategic changes in its future implementation, in order to minimize the risk of unpaid debt (credit crunch) and improve the performance of SMEs groups. This change emphasizes that the loans granted to SMEs should be accompanied by the empowerment of SMEs so that SMEs have the knowledge to manage debt and increase capacity for their business development.

On the channeling pattern, it is found that there is lending which is not on target, namely the loans that not for production, but used for consumption, which leads to the inability to repay the loan, this is in line with the research results conducted by Suji, Sutomo, and Mukti (2015) who found the misuse of the People's Business Credit (KUR) which was originally for the production, the reality on the way it is used for consumption rather than investment that can benefit their business. This study is also consistent with research conducted by Purnamayanti, Suhendra, and Yulianthini (2014) who found that SMEs income decreased after receiving credit assistance. However, this research is on contrary to the opinion of Kashmir (2010) who states that the credit can positively increase revenues because the loans can increase the business capital.

Channeling pattern also showed that the mistargeted is seen from the incompatibility between the type of business and local geographical circumstances, means that the government in giving credit does not analyze whether the type of business is in accordance with the geographical conditions or not. It is proven, like in flood-prone areas, they attempt to make fish pond business, thus make the fish farmers do not succeed. And it will affect the growth of the business. Not on target both credit used for consumption and incompatibility of business with its geographic condition is more prevalent in the group of jammed payment due most of the people in the group considers the funds provided by the government are grants that do not require having to be returned.

The behavior of customers on channeling patterns is still reluctant to perform the obligation because it still considered a government grant. Therefore, the government through the related local government offices continue to perform continuous billing to customers which are classified as nonperforming loans is able to repay its obligations, then channeling pattern should return to the pattern of executing, involving Jambi Bank as executor of lending implementation, doing credit analysis and has the legal authority to follow up on violations of the inability to repay the loans granted by the Provincial Government of Jambi.

By making a change in the implementation of channeling pattern to executing patterns, where the responsible party for assessing creditworthiness is done by the Jambi Regional Development Bank, as well as responsibility for collecting the debts from the customers. Thus, the supervision and implementation of the use of funds from the government can be done to the right target and in 
Table 3.

SWOT Analysis on the Strategy of KUPEM Implementation for the People of Jambi

\begin{tabular}{|c|c|c|}
\hline IFAS & STRENGTHS & WEAKNESSES \\
\hline $\begin{array}{r}\text { (Internal Strategic } \\
\text { Factor Analysis Summary) }\end{array}$ & $\begin{array}{l}\text { - KUPEM loan provisions already in } \\
\text { accordance with the applicable rules } \\
\text { - There is an assessment for credit } \\
\text { repayment } \\
\text { - KUPEM terms of payment have } \\
\text { been based on mutual agreement in } \\
\text { accordance with the income business } \\
\text { cycle and the ability of the borrowers }\end{array}$ & $\begin{array}{l}\text { - Lack of guidance to SMEs in managing } \\
\text { their business } \\
\text { - The weakness of suitability analysis } \\
\text { between business type and the area' } \\
\text { potential } \\
\text { - Lack of socialization to the prospective } \\
\text { borrowers regarding the liability and } \\
\text { sanctions that should be fulfilled } \\
\text { - Analysis of the financial statements of } \\
\text { prospective borrowers had not been } \\
\text { effective }\end{array}$ \\
\hline OPPORTUNITIES & S-O & w - o \\
\hline $\begin{array}{l}\text { - IKM has had behavioral attitudes which } \\
\text { are not discouraged and conscientious in } \\
\text { doing business } \\
\text { - Personal factors such as the urge to } \\
\text { succeed are more dominant } \\
\text { - SMEs groups have the nature and } \\
\text { behavior of being careful in running the } \\
\text { business to avoid failure. } \\
\text { - The encouragement from inner side to } \\
\text { succeed and become an example of other } \\
\text { SMEs }\end{array}$ & $\begin{array}{l}\text { - Carry forward further credit assistance } \\
\text { program for the development of SME } \\
\text { - Realizing the SMEs that have innovative } \\
\text { and creative behavior }\end{array}$ & $\begin{array}{l}\text { - The existence of guidance in the form of } \\
\text { - Strempaniment in managing the business } \\
\text { suitability } \\
\text { - Disseminating information to all creditors } \\
\text { of the obligations and sanctions that must } \\
\text { be executed } \\
\text { - Financial statements as credit terms. }\end{array}$ \\
\hline THREATS & $S-T$ & W-T \\
\hline $\begin{array}{l}\text { - Lack of knowledge of SMEs in terms } \\
\text { of bookkeeping, and enhancing the } \\
\text { entrepreneurial skills } \\
\text { - Social factors affecting SMEs in } \\
\text { determining business attitudes and } \\
\text { behaviors } \\
\text { - In doing business not yet oriented to } \\
\text { achieving the target }\end{array}$ & $\begin{array}{l}\text { - Strengthen the ability of the relevant } \\
\text { authorities, through the Human Resources } \\
\text { ability to continue giving assistance to } \\
\text { improve the ability of SME actors } \\
\text { - Through the related department to make } \\
\text { associations among groups of SMEs } \\
\text { - Increasing motivation to work through } \\
\text { counseling activities }\end{array}$ & $\begin{array}{l}\text { - Optimization of SME actors capabilities } \\
\text { through business mentoring } \\
\text { - Providing training programs according to } \\
\text { the needs of SMEs }\end{array}$ \\
\hline
\end{tabular}

accordance with the type of business. Furthermore, to enhance the performance of SMEs, the government should empower, to shape the ability of SMEs in managing credit funds into a source of income to improve welfare.

Thereby, the loans given can really help and can increase the income of economic actors (SMEs). This is in line with the results of research conducted by Saad Murdy (2010) on the Role KUPEM in Increasing Potato Production in Kerinci District. The results showed that farmers earn benefit from KUPEM fund, where capital assistance is able to increase the income of farmers through increased production of potatoes.

Research that supported the loans as an effort to improve the welfare is done by Setyari (2012) titled "Impact Evaluation of Microcredit on Household Welfare in Indonesia." The results show that (1) after receiving credit, the household spending is greater, it is showed improved earnings, the absence of domestic workers who are unemployed, even there is a reallocation of time, in which school children participated in doing business which is financed by microcredit.
Another strategy that should be changed can be seen in Table 3.

Based on the SWOT analysis in Figure 4 which is quantitative SWOT analysis and Table 1 which is qualitative SWOT analysis, thus the ideal strategy for the implementation of KUPEM programs for the people in Jambi Province are:

\section{1) Strength-Opportunity Strategy $(S-O)$}

Strategy that prioritize strengths and take advantage of opportunities, this strategy is used to support aggressive growth policies, such as:

a. Provide further credit assistance program for the development of SME (meaning KUPEM continued by changing the channeling pattern into executing patterns).

2) Strength-Threat Strategy $(S-T)$

Strategy used to utilize the strength to overcome the threat by:

a. Strengthening the capacity of relevant agencies to create mentoring and coaching programs to enhance the ability of SME actors

b. Through the relevant agencies to form 
associations between groups of SMEs

c. Increasing motivation to work through counseling activities

3) Weakness Opportunity Strategy $(W-O)$

A strategy that minimizes internal weaknesses by taking advantage of opportunities to improve internal conditions became a source of new powers for the ideal implementation KUPEM.

a. Guidance or assisting program for businesses

b. Strengthen the analysis for the type of business compatibility

c. Socialization to all creditors regarding the liabilities and sanctions of KUPEM

d. The financial statements as credit terms

4) Weakness Threat Strategy $(W-T)$

Strategy that leads to internal weaknesses in order to survive (defensive) in the face of challenges, they are:

a. Optimization of socialization and motivation towards SMEs

b. Improving the capacity of human resource educator

\section{Conclusion}

The result of SWOT analysis quantitatively and qualitatively through S-O strategy, the government should continue to implement further credit assistance program for the development of SMEs by making strategic changes, one of which is the restoring the pattern from channeling back to executing patterns. Through the S-T strategy, the government has to develop mentoring or coaching programs for SME groups and forming associations. Through a strategy of $\mathrm{W}-\mathrm{O}$, Jambi Provincial Government through relevant agencies associated with the group of SMEs, before giving loans they should analyze the compatibility of business with the potential of SMEs and the market, to provide guidance on business management in the form of financial reporting, and dissemination of information to all creditors regarding the liability and sanctions of KUPEM. Through W-T strategy, there should be an improvement in educator agents in each agency associated with the group of SMEs.

\section{SUGGESTION}

KUPEM is a government program to improve the ability of businesses through financial assistance with low interest. So that businesses can thrive, it needs government support to enhance the ability of educator officers in every relevant working unit (SKPD) according to the type of SME, so mentoring and coaching to improve the ability of SMEs can be done optimally. There is a need for cooperation between SKPD and Bank of Jambi, before the credit is disbursed there should be a recommendation from relevant SKPD regarding the suitability of the type of business with the local conditions (in this case the state of nature, public taste, and the target market) to avoid failure in the attempt. It is needed to do a study of the strategy to build the capacity of SMEs to enhance the creative and innovative behavior.

\section{ACKNOWLEDGEMENT}

The author expressed her gratitude to the Research and Development Agency of Jambi Province that have provided funding for this study. The greatest appreciation also goes to Jambi Bank, Department of Economic and Development and the District Municipality in Jambi Province that have supported the implementation of research activities so that this research could be finished well.

\section{REFERENCES}

Diagne, A., \& Zeller, M. (2001). Access to Credit and Its Impact on Welfare in Malawi. Research Report International Food Policy Research Institute. Retrieved from http://search.ebscohost.com/ login.aspx ?direct $=$ true $\& \mathrm{db}=\mathrm{eoh} \& \mathrm{AN}=058524$ $4 \&$ site $=$ ehost-live

Diagne, A., Zeller, M., \& Sharma, M. (2000). Empirical Measuremnets of Households' Access to Credit and Credit Constraints in Developing Contires: Methodological Issues and Evidence. Food Consumption and Nutrition Division. International Food Policy Research Institute, 90(90), 1-73.

Feder, G., Lau, L. J., Lin, J. Y., \& Luo, X. (1990). The Relationship between Credit and Productivity in Chinese Agriculture: A Microeconomic Model of Disequilibrium. American Journal of Agricultural Economics, 72(5), 1151-1157. http://doi.org/10.2307/1242524

Ferdian, R. (2004). Pemberdayaan Usaha Kecil Masyarakat melalui Program Pemberdayaan Ekonomi Rakyat (PER) di Kota Sabang: Studi Kasus Pemberian Kredit Lunak kepada Usaha Kecil Masyarakat di Kota Sabang. Universitas Indonesia.

Hadi, S. (1993). Statistik 2. Yogyakarta: Andi.

ILO. (1991). The Dilemma of the Informal Sector: Report of the Director-General. In The 78th Session of the International Labour Conference, Geneva. Geneva: ILO.

Kasmir. (2010). Manajemen Perbankan (9th ed.). Jakarta: Raja Grafindo Persada.

Kementerian Perdagangan. (2013). Analisis Peran Lembaga Pembiayaan dalam Pengembangan UMKM. Jakarta.

Kurniawan, F. D., \& Fauziah, L. (2014). Pemberdayaan Usaha Kecil dan Menengah (UMKM) dalam Penanggulangan Kemiskinan. JKMP, 2(2), 102- 
220.

Mukti, C. (2015). Evaluasi Dampak Program Pemberdayaan Masyarakat Melalui Penyaluran Kredit Usaha Rakyat di Desa Sumber Lesung Kecamatan Ledokombo Kabupaten Jember. Universitas Jember. Retrieved from http://repository.unej.ac.id/ bitstream/handle/123456789/65672/Ainul Latifah-101810401034.pdf?sequence $=1$

Munawir. (2002). Analisis Informasi Keuangan. Yogyakarta: Liberty.

Murdy, S. (2010). Peranan Kupem dalam Meningkatkan Produksi Kentang di Kabupaten Kerinci. Jurnal Sosio Ekonomika Universitas Jambi, 13(1), 1-13.

Pearce II, J. A., \& Robinson, R. B. (2008). Manajemen Strategis (Formulasi, Implementasi, dan Pengendalian). Jakarta: Salemba Empat.

Purnamayanti, N. W. A., Suwendra, I. W., \& Yulianthini, N. N. (2014). Pengaruh Pemberian Kredit dan Modal terhadap Pendapatan UKM. E-Journal Bisma Universitas Pendidikan Ganesha, 2.

Sabirin, S. (2001). Pemanfaatan Kredit Mikro untuk Mendorong Pertumbuhan Ekonomi Rakyat di dalam Era Otonomi Daerah. In Orasi Ilmiah Lustrum IX Universitas Andalas. Padang: Universitas Andalas.

Salusu, J. (2003). Pengambilan Keputusan Stratejik untuk Organisasi Publik dan Organisasi Non Profit. Jakarta: Grasindo.

Saragih, F. (2015). Analisis Penerapan Akuntansi dan Kesesuaiannya dengan SAK ETAP pada UKM Medan Perjuangan. In Seminar Nasional Ekonomi Manajemen dan Akuntansi (SNEMA) Fakultas Ekonomi Universitas Negeri Padang (pp. 452-461). Padang: Universitas Negeri Padang.

Sarosa, W. (2000). Menyoroti Sektor Informal Perkotaan. Retrieved August 7, 2015, from http://www.urdi.org/urdi/bulletin/volume12a.php

Sekaran, U. (2006). Research Methods for Business: A Skill-Building Approach (4th ed.). Toronto: Wiley.

Setyari, N. P. W. (2012). Evaluasi Dampak Kredit Mikro terhadap Kesejahteraan Rumah Tangga di Indonesia: Analisis Data Panel. Jurnal Ekonomi Kuantitatif Terapan, 5(2), 141-150.

Soehartono, I. (2001). Metode Penelitian Sosial. Bandung: Rineka Cipta.

Suryana. (2003). Kewirausahaan: Pedoman Praktis Kiat dan Proses Menuju Sukses. Bandung: Salemba Empat.

Zeller, M., Ahmed, A., Babu, S., Broca, S., Diagne, A., \& Sharma, M. (1996). FCND Discussion Papers contain preliminary material and research results, and are circulated prior to a full peer review in order to stimulate discussion and critical comment. It is expected that most Discussion Papers will eventually be published in some. FCND Discussion Paper, (11).

Kesepakatan Kerjasama antara Gubernur Jambi dengan Direksi Bank Pembangunan Daerah Jambi tentang Perubahan Program Executing menjadi Channelling, Pub. L. No. 01/PERj/ OHK/I/2004 \& 02.01.KP/DIR 2004 (2004). Indonesia.

Law of the Republic of Indonesia No 24 of 2004 on the Deposit Insurance Agency, Pub. L. No. 24 (2004). Indonesia. 